\title{
FENOMENA GEGAR BUDAYA PADA WARGA NEGARA PERANCIS YANG BEKERJA DI JAKARTA
}

\author{
Yusnia Khoirunnisa ${ }^{1}$, Nathalia Perdhani Soemantri ${ }^{2 *}$ \\ Faculty of Communication Studies, Universitas Pancasila, Jakarta, Indonesia.
}

\section{ARTICLE INFORMATION}

Submitted : 09 September 2019

Review : 03 November 2019

Accepted : 03 December 2019

Available online: December 2019

\section{KEYWORDS}

Cultural communication, Cultural shock, French citizens

\section{CORRESPONDENCE}

*E-mail: nathaliaperdhani@univpancasila.ac.id

\section{A. PENDAHULUAN}

$\mathrm{S}$ etiap hari dimanapun kita berada tidak bisa terlepas dari komunikasi. Bisa dikatakan bahwa komunikasi merupakan hal yang terpenting atau vital bagi manusia tanpa komunikasi maka manusia dikatakan "tersesat" dalam belantara kehidupan ini. "Orang yang tidak pernah berkomunikasi dengan manusia bisa dipastikan 'tersesat', karna ia tidak bisa menaruh dirinya dalam lingkungan sosial" (Mulyana, 2008:5). Komunikasi manusia tidak terjadi dalam ruang hampa sosial, komunikasi terjadi dalam suatu lingkungan sosial yang kompleks. Lingkungan sosial ini merefleksikan bagaimana orang hidup, bagaimana iya berinteraksi dengan orang lain. lingkungan sosial adalah budaya, dan untuk benar-benar memahami komunikasi maka harus memahami budaya (Sihabudin, 2017:18).

Manusia berpikir dan bertindak sesuai dengan pola budaya yang telah melekat pada dirinya. Budaya menjadi bagian dari perilaku komunikasi, dan pada gilirannya komunikasi pun turut menentukan, memelihara, mengembangkan atau mewariskan budaya. Ketika individu masuk dalam lingkungan budaya baru akan mengalami kesulitan bahkan tekanan mental karena telah

\section{A B S T R A C T}

The cultural shock will be increasingly visible if the newcomer has a cultural origin that is far different from the new culture he is attending. This study aims to see how the phenomenon of culture shock that occurs in French citizens who work in Jakarta. The concept used as a knife of analysis in this study is the concept of Cultural Communication and Cultural Concentration, which includes stages, phases, and forms of Cultural Concussion. The method of this research is using descriptive qualitative with the main data collection obtained from the results of interviews with three French citizens who work in Jakarta. The results showed that the three French citizens experienced a cultural shock in the form of language, food, weather, attitude, order. The cultural shock reactions experienced by them are feeling confused, stressed, homesick, physically ill, and always compare everything with their home country. The stages of cultural shock experienced by French citizens, namely the phase of excitement, the phase of disappointment, the initial phase of resolution and the phase function effectively.

terbiasa dengan hal-hal yang ada disekelilingnya. Salah satu kecemasan yang terbesar adalah mengenai bagaimana harus berkomunikasi. Ketika individu masuk dan mengalami kontak budaya lain serta merasakan ketidaknyamanan psikis dan fisik karena kontak tersebut, maka keadaan ini disebut sebagai gegar budaya atau culture shock. Culture shock didefinisikan sebagai kegelisahan yang mengendap yang muncul dari kehilangan tanda-tanda dan lambang-lambang yang familiar dalam hubungan sosial. Tanda-tanda atau petunjuk-petunjuk itu meliputi seribu satu cara yang kita lakukan dalam mengendalikan diri kita sendiri dalam menghadapi situasi sehari-hari (Mulyana dan Rahmat, 2006:174).

Sangat wajar apabila seseorang yang masuk dalam lingkungan budaya baru mengalami kesulitan bahkan tekanan mental karena telah terbiasa dengan hal-hal yang ada. Pada kenyataannya seringkali kita tidak bisa menerima atau merasa kesulitan menyesuaikan diri dengan perbedaan-perbedaan yang terjadi akibat interaksi tersebut, kebiasan yang berbeda dari seorang teman yang berbeda asal daerah atau cara-cara yang menjadi kebiasaan (bahasa, tradisi atau norma) dari suatu daerah sementara 
kita berasal dari daerah lain (Sekeon, 2011:3). Penelitian Ajeng (2016) mengenai Tenaga Kerja Indonesia yang bekerja di Korea menjelaskan bahwa TKI mengalami culture shock yang berbeda-beda pada dirinya ketika pertama kali datang ke Korea Selatan. Culture shock yang dialami adalah penyesuaian terhadap perbedaan iklim musim dingin, kelemahan tubuh dan penyesuaian terhadap makanan.

Seseorang menjadi wajar mengalami culture shock sebagai akibat perpindahannya dari lingkungan yang lama ke lingkungan yang baru. Gegar budaya yang dialami selain dengan bahasa yaitu terikait masalah perbedaan musim atau cuaca dan makanan. Faktor geografis atau perbedaan letak wilayah menjadi penyebab terjadinya perbedaan cuaca atau musim (Ridwan, 2016:210). Selain itu faktor makanan juga menjadi penyebab terjadinya culture shock karena disetiap wilayah atau Negara memiliki makanan khasnya tersendiri. Ridwan (2016:12) juga memberi pengertian bahwa budaya atau kebudayaan diartikan sebagai hal yang berkaitan dengan budi dan akal manusia. Kebudayaan sebagai sesuatu turun temurun dari satu generasi ke generasi lain.

Kebiasaan makan, bahasa, persahabatan, praktik komunikasi, tindakan-tindakan sosial, kegiatan ekonomi, politik dan teknologi semua itu berdasarkan pola-pola budaya. Apa yang dilakukan bagaimana mereka bertidak, merupakan respons terhadap fungsi-fungsi budayanya (Sihabudin, 2017:19). Individu yang memasuki alam kebudayaan baru yang berbeda dari tempat asalnya akan merasakan kegelisahan dalam dirinya, hal tersebut terjadi akibat dari perbedaan budaya (Ridwan 2016:200). Hal itu terjadi secara alamiah dan terkadang berubah menjadi rasa takut, frustasi dan tidak percaya diri pada orang yang mengalaminya. Penelitian Marnelly (2017) mengungkapkan bahwa perubahan terjadi karena adanya kontak dengan budaya baru dan karena adanya ketidakpuasan masyarakat terhadap bidang-bidang kehidupan tertentu, orientasi masa depan dan nilai bahwa manusia harus senantiasa berikhtiar untuk memperbaiki hidupnya.

Gegar budaya akan semakin terasa jika jarak perbedaan budaya semakin jauh. Negara Perancis adalah salah satu Negara yang berada di Benua Eropa. Banyak pekerja asal Negara Perancis yang kemudian datang dan bekerja di Indonesia dan mengalami gegar budaya karena jauhnya perbedaan budaya antara kedua Negara tersebut. Ridwan (2016:215) menyebutkan ada 6 jenis gegar budaya yang biasa dirasakan akibat perbedaan budaya yaitu kategori bahasa, makanan, musim/cuaca, sikap/perilaku, ekonomi, dan ketertiban. Sedangkan Samovar et.al, (2017:277) menyebutkan bahwa fase gegar budaya biasa digambarkan dengan kurva $U$ yaitu berupa fase kegembiraan, fase kekecewaan, fase awal resolusi, dan fase berfungsi secara efektif.
Berdasarkan pemaparan latar belakang masalah di atas, maka perumusan masalah maka penelitian ini ingin mendeskripsikan bagaimana bentuk dan tahapan gegar budaya yang dialami warga negara Perancis saat bekerja di Jakarta.

\section{B. METODE}

$\mathrm{P}$ enelitian ini menggunakan paradigma interpretetif. Menurut Craswell (2015:11) paradigma Interpretetif meneguhkan asumsi bahwa individu-individu selalu berusaha memahami dunia dimana mereka hidup dan bekerja. Paradigma interpretetif digunakan pada penelitian ini dengan upaya untuk memahami realitas pengalaman manusia. Paradigma ini bersifat subjektif. Meninjau masalah dari penelitian. Paradigma ini membantu dalam memahami, memaknai dan menginterpretasikan permasalahan yang ada dalam fenomena gegar budaya pada pekerja asing Negara Perancis yang bekerja di Jakarta.

Pendekatan penelitian yang digunakan dalam penelitian ini adalah kualitiatif, menurut (Pujilek sono, 2015:35) penelitian kualitatif berusaha menjelaskan realitas dengan menggunakan penjelasan deskriptif dalam bentuk kalimat. Peneliti membuat suatu gambaran kompleks, meneliti kata-kata, laporan terinci dari pandangan responden, dan melakukan studi pada situasi yang alami.

Peneliti menggunakan jenis penelitian deskriptif. Neuman (2015:53) menelaskan bahwa penelitian deskriptif bertujuan untuk memberikan gambaran dengan menggunakan kata dan angka serta untuk menyajikan profil, klarifikasi jenis atau garis besar tahapan guna menjawab pertanyaan seperti kapan, dimana dan bagaimana. Tidak hanya itu jenis penelitian deskriptif ini lebih berfokus juga kepada pertanyaan "siapa" dan "bagaimana" dalam menyajikan gambarannya.

Teknik pengumpulan data yang digunakan adalah wawancara, observasi non partisipan, dan dokumentasi. Informan kunci dipilih berdasarkan fenomena yang diteliti yaitu mengenai fenomena gegar budaya pekerja asing asal Negara Perancis, oleh karena itu agar data objektif dapat diperoleh, maka peneliti menetapkan bahwa informan utama dalam penelitian yaitu pekerja asing Negara Perancis. Adapun pekerja tersebut memiliki kriteria sebagai berikut:

a. Pekerja asing berwarga Negara Perancis yang lahir dan besar di Negara Perancis

b. Pekerja asing warga Negara Perancis yang bekerja lebih dari 6 bulan di Jakarta. Dengan asumsi bahwa seluruh tahapan Gegar Budaya telah dilewati dalam jangka waktu tersebut.

Peneliti menggunakan observasi non-partisipan yaitu suatu bentuk observasi dimana peneliti tidak terlibat langsung dalam kegiatan kelompok, atau tidak ikut serta dalam kegiatan yang 
diamatinya. Menurut Creswell (2015:17) Pengamatan atau observasi adalah cara pengumpulan data dengan terjun dan melihat langsung ke lapangan terhadap objek yang diteliti, pengamatan tersebut juga disebut peneliti lapangan.

\section{HASIL DAN PEMBAHASAN \\ 1. Data informan}

\section{a. Gerald Bernardin}

Gerald Benardin adalah salah seorang manager Vinci Contruction pada bagian Logistic \& plant, Superintendent. Gerald lahir di Aix en Provence (Perancis bagian selatan) pada tanggal 12 Juli 1990. Agama yang dianut yaitu Islam. Pendidikan yang pernah dijalani yaitu Management Communication Marketing, Skill Structur Contruction. Gerald berkarir menjadi metalic structur hingga umur 23 tahun. Dirinya memulai bekerja dengan Perusahaan Vinci pada tahun 2013 hingga sekarang. Awal tahun 2017 Gerald menetap di Jakarta untuk mengerjakan projek yang berjalan 8 bulan.

b. El Mehdi El Alami

El Mehdi El Alami bekerja pada bagian MEP Manajer. Beragama islam, belum menikah. Lahir di Negara Perancis di Paris pada tanggal 16 Agustus 1986. Pendidikan yang dijalaninya yaitu bersekolah di bidang listrik, yang kedua menempuh pendidikan di bidang tehnik, selanjutnnya menjalani pendidikan di spesifik untuk kontraktor. Sejak sekolah di bagian tehnik dirinya juga menjalani pekerjaan di perusahaan Vinci hingga sekarang.

\section{c. Louis Franchois}

Louis Franchois yang lahir pada tanggal 27 Januari 1989 di kota Lil bagian utara Negara Perancis. Louis beragama kristen. Bekerja di bagian Trades Manager. Pada proyek pekerjaannya di Jakarta Louis menetap selama 8 bulan. Louis menjalani pendidikannya jurusan tehnik management.

\section{Fase Gegar Budaya yang dialami warga Negara Perancis di Indonesia}

Meskipun ada banyak variasi dari bagaimana orang memberikan tanggapan terhadap gegar budaya dan jumlah waktu yang dibutuhkan dalam menyesuaikan diri. Seseorang biasanya melewati empat tahapan gegar budaya. Keempat tahapan tersebut dapat digambarkan sebagai kurva berbentuk "U". Sehingga disebut u-curve. Kurva$U$ menggambarkan keoptimisan dan kebahagiaan terhadap budaya tuan rumah, level adaptasi, dan berikutnya masa penyembuhan (Samovar et al, 2017:477).

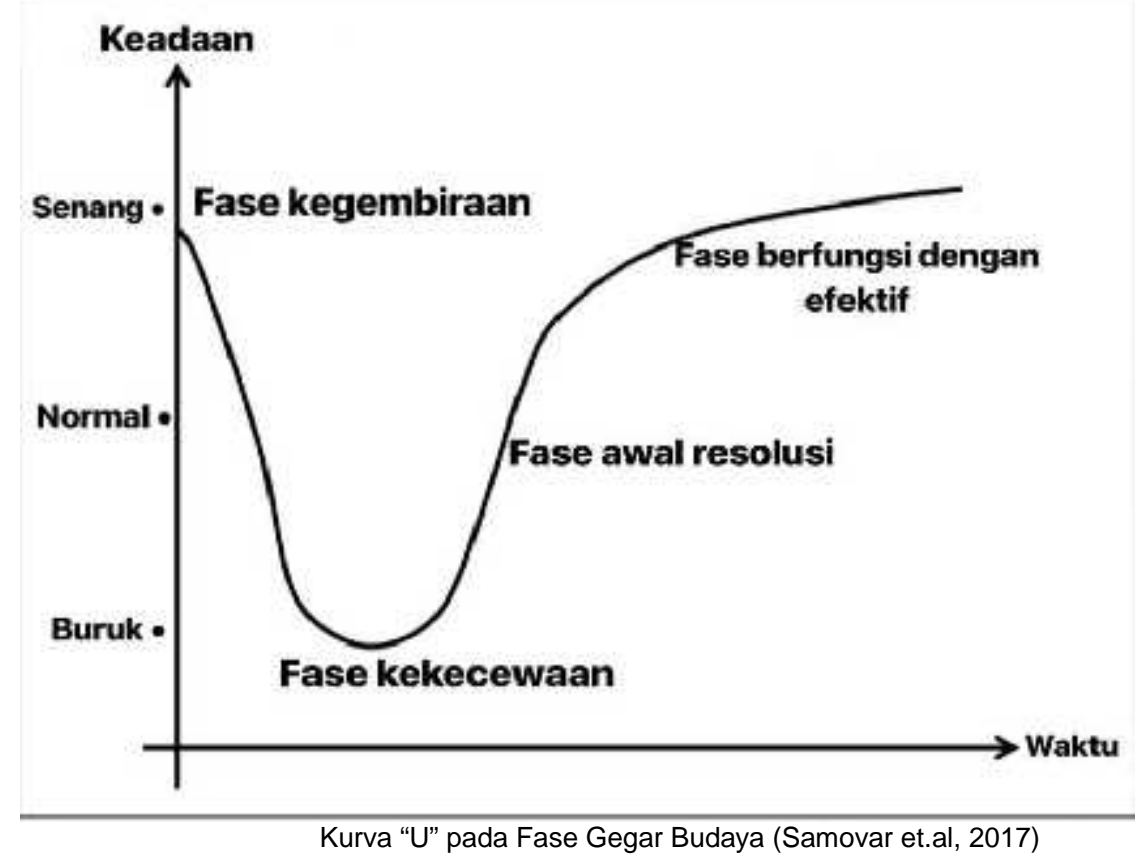

Berikut adalah penjelasan mengenai fasefase gegar budaya yang dialami oleh pekerja asing asal negara Perancis di Indonesia:

\section{A. Fase Kegembiraan}

Tahapan atau fase tersebut diawali dengan fase kegembiraan atau tahap Honeymoon. Fase ini berisi kegembiraan, rasa penuh harapan, dan euforia sebagai antisipasi individu ketika berhadapan dengan budaya yang baru. Dibuktikan dari ketiga informan asal Negara Perancis yang datang ke Negara Indonesia untuk bekerja di Jakarta. Mereka merasakan harapan akan lingkungan barunya ketika pertama kali datang, seperti mengatakan bahwa Negara Indonesia yang banyak budaya, di kota Jakarta yang 
menjadi ibu kota Indonesia yang besar dan banyak masyarakat yang menetap untuk bekerja dari kebudayaan berbeda, kota yang sibuk dengan kantor-kantor yang banyak di Jakarta, kota yang bersih. Dari observasi yang peneliti lakukan terlihat perasaan senang ketika menjelaskan pertama kali datang ke lingkungan barunya.

\section{B. Fase Kekecewaan}

Tahap kedua adalah Fase Kekecewaan. Dirasakan ketika menyadari kenyataan bahwa berada dilingkungan yang berbeda. Serta masalah awal mulai berkembang. Misalnya kesulitan adaptasi dan komunikasi, kesulitan bahasa, tempat tinggal yang kualitasnya buruk, transportasi yang sesak, pusat perbelanjaan yang berbeda, dan sebagainya. Hal ini dirasakan oleh pekerja asal Perancis yang bekerja dijakarta ketika sulit untuk berkomunikasi dengan bahasa. Karena ketiga informan pekerjaannya di bidang kontraktor, yaitu pembangunan mereka bekerja dengan berhadapan langsung pada pekerja pribumi. Dari ketiga informan yang paling merasakan kesulitan dalam berkomunikasi dengan para buruh bangunan adalah informan Gerald yang berprofesi sebagai manajer bagian lapangan, sehingga dirinya harus harus memantau setiap hari pekerjaan yang dilakukan oleh buruh bangunan dan membuatnya merasa lelah ketika komunikasi tidak berjalan lancar. Disampaikan olehnya bahwa mereka menjawab mengerti tetapi kenyataannya tidak mengerti. Serupa dengan pendapat informan Mehdi mengenai kesulitannya dalam komunikasi bahasa.

Fase ini kadang ditandai oleh rasa kaget, kecewa, bingung dan ketidakpuasan. Hal ini adalah periode krisis dalam gegar budaya. Orang- orang menjadi bingung dan tercengang dengan sekitarnya, dan rasa frustasi membuat mudah tersinggung, memiliki sifat bermusuhan, mudah marah, tidak sabar, dan bahkan tidak mampu. Dalam kasus ekstrem, perasaan tidak nyaman tersebut akan menjadi perasaan benci terhadap segala sesuatu yang asing. Bagi pekerja asal Perancis banyak hal yang berbeda dari kebudayaannya, hal tersebut yang membuat mereka merasa bingung. Seperti dengan keadaan lalu lintas di Jakarta, kondisi cuaca atau musim yang berbeda, dapat diketahui bahwa musim di Negara Perancis terdapat empat musim sehingga cuaca yang di Jakarta tepatnya ketika hujan yang dikatakan aneh karena setelah panas hujan lebat. Adapun sikap bekerja buruh bangunan yang kurang tepat waktu, pakaian bekerja. Selanjutnya mengenai makanan serta peraturan pada pedagan makanan yang berada di pinggir jalan trotoar.

\section{Fase Awal Resolusi}

Fase ketiga dimana seseorang mulai memahami mengenai budaya barunya. Pada tahap ini, seseorang secara bertahap akan membuat penyesuaian dan perubahan dalam caranya menagani budaya baru. Menurut para pekerja asing asal Perancis, pada fase ini mereka menemukan cara dan solusi atas masalah-masalah yang ada mengenai perbedaan budaya. Ditandai mempelajari bahasa sehari-hari yang mudah digunakan dan dimengerti. Para pekerja lebih berani menjelaskan dengan bahasa mereka. Para pekerja bagunan mengerti dan mulai tepat waktu sehingga kesalahan-kesalahan yang sebelumnya terjadi bisa diatasi. Peristiwa dan Orang-orang dalam lingkungan baru mulai dapat terprediksi dan tingkat stres tidak banyak. Karena sikap saling menghargai dari perbedaan budaya yang membuat para pekerja asal Negara perancis mulai di tahap memahami lingkungan sekitar, ingin mengetahui mengenai budaya yang ada, mencoba makanan khas dari Indonesia, belajar menggunakan bahasa Indonesia.

\section{Fase Berfungsi dengan Efektif}

Fase terakhir ini berada pada puncak kanan dari kurva-U. seseorang telah mengerti elemen kunci dari budaya barunya seperti nilai-nilai, adab khusus, pola komunikasi, keyakinan, dan lainlain. Pada tahap ini para pekerja asal Perancis muncul sikap santai dan lebih mampu untuk memahami orang lain dan menerima keadaan budaya sekitar. Kemudian mulai merasakan kenyamanan dengan orang-orang sekitar lingkungannya dalam budaya yang berbeda.

Pada tahap ini orang merasa nyaman dalam budaya baru dan mampu bekerja dengan baik. tidak hanya merasakan kenyamanan terhadap lingkungan melainkan kenyamanan di tempat tinggalnya, kenyamanan dengan makanan dan sebagainya. Seperti yang dikatakan oleh ketiga informan asal Perancis bahwa di Jakarta sangat mudah dalam mencari makanan dari Negara asalnya, banyak restoran yang menyediakan makanan Perancis serta toko roti Perancis. Tidak hanya bahagia dengan makanan asal negaranya, mereka juga banyak menyukai makanan khas Indonesia yang ada di Jakarta, seperti nasi goreng, sop, sate, rendang, iga sop. Kesukaannya terhadap makanan Indonesia menandakan juga bahwa mereka sudah sangat nyaman dengan lingkungan barunya.

\section{Jenis Gegar Budaya yang di alami pada warga Negara Perancis}

a) Kategori Bahasa

Bahasa merupakan alat utama yang digunakan budaya untuk menyalurkan kepercayaan, nilai dan moral. Bahasa berfungsi sebagai suatu mekanisme untuk berkomunikasi dan pedoman untuk melihat realitas sosial. Ridwan (2016:119) menyatakan bahwa bahasa adalah 'verbal". Bahasa merupakan cerminan dari budaya, yakni isi budaya dan natur budaya. 
Dalam banyak tindakan komunikasi, bahasa nonverbal menjadi komplemen atau pelengkap bahasa verbal. Lambang-lambang nonverbal juga dapat berfungsi kontradiktif, pengulangan, bahkan penganti ungkapan verbal. Dalam hal ini pekerja asal Negara Perancis merasakan permasalah yang ada yaitu pada bahasa. Pekerja asing ini tidak mampu menggunakan bahasa Indonesia dan pekerja buruh bangunan tidak bisa menggunakan bahasa inggris. Sehingga keinginan dari pekerja Perancis yaitu kepala yang bertanggung jawab membawa pekerja bagunan dapat berkomunikasi dengan lancar menggunakan bahasa inggris, namun kenyataannya tidak sesuai dan mengakibatkan banyak kesalapahaman.

Kesalapahaman karena bahasa yang tidak dimengerti mengakibatkan pekerjaan yang lambat, sehingga para pekerja asal Negara perancis mencari solusi yaitu mencampur bahasa Indonesia yang umum dengan bahasa inggris sebaliknya pada para pekerja buruh bangunan juga menggunakan bahasa nonverbal dalam berkomunikasi. Seperti yang diungkapkan oleh Ridwan (2016:156) bahwa Bahasa verbal ataupun nonverbal merupakan bentuk pesan yang digunakan oleh manusia untuk mengadakan kontak dengan realitas lingkungannya.

Kemampuan manusia untuk menggunakan simbol menjadikannya sebagai makhluk yang unik, yang membedakannya dari makhluk hidup lainya. Bagi para pekerja asal Perancis sudah mengetahui apabila para pekerja buruh bangunan yang tidak mengerti maksud mereka, solusi yang dilakukan yaitu dengan bahasa tubuh, menunjuk, menjelaskan dengan gambar dan turun langsung menjelaskan lebih maksimal untuk benar-benar dimengerti. Dan menghasikan kepuasan pada pekerja asal Perancis.

\section{b) Kategori Makanan}

Faktor makanan juga menjadi penyebab terjadinya gegar budaya karena disetiap Negara memiliki ciri khas mengenai makanan, seperti contohnya Negara Perancis yang terkenal dengan makanan keju, roti, pasta. Sedangkan Negara Indonesia memiliki banyak makanan dengan berbagai macam rasa. Salah satunya makanan Indonesia terkenal dengan makanan pedas. Permasalahan dengan makanan pada warga Negara perancis adalah mereka tidak bisa memakan pedas, ungkapan tersebut dikatakan oleh informan Louis, dan informan Gerald menyatakan bahwa dirinya sempat sakit akibat makanan yang pedas. Serta Gerald mengatakan bahwa perbedaan dari makanan utama di Indonesia dan Perancis adalah nasi dan makanan dari Perancis yaitu kentang atau pasta.

Ketiga informan berpendapat menyukai makanan Indonesia, seperti Nasi goreng, sate, sop, rendang, sop iga. Dari ketiga informan teersebut satu diantaranya yaitu Meidi menyukai pedas tetapi tidak dengam memakan sambal.
Karena di Negara Perancis rasa pedas yang ada berasal dari krim atau bubuk paprika dan minyak yang dicampur dengan cabai yang tidak sepedas di Indonesia. Adapun hal yang membuat pekerja asal Perancis terkejut dengan banyaknya makanan yang dijual di perbatasan jalan, di negaranya hal tersebut tidak akan ada karena untuk membuat usaha perlu izin dari gubernur.

\section{c) Kategori Cuaca/Musim}

Gegar budaya yang dialami selain dengan bahasa, makanan yaitu terikait masalah perbedaan musim atau cuaca. Faktor geografis atau perbedaan letak wilayah menjadi penyebab terjadinya perbedaan cuaca atau musim (Ridwan, 2016:210). Para pekerja asal Negara perancis ketika pertama kali mejekjakan kakinya di ibu kota Jakarta merasakan perbedaan dari udara yang terlalu banyak polusi. Cuaca yang tidak menentu, seperti hujan yang turun sangatlah besar, hal tersebut sangatlah berbeda dengan Negara asalnya Perancis yang memiliki 4 musim.

Meidi mengatakan bahwa cuaca yang buruk dan ketika hujan turun mengakibatkan banjir. Dirinya kaget dengan keadaan tersebut. Gerald juga mengatakan bahwa cuaca yang aneh karena ketika siang hari sangatlah panas terik dan sore hari turun hujan.

\section{d) Kategori Peraturan Lalu Lintas/ ketertiban}

Jakarta merupakan ibu kota Negara Indonesia, Sehingga banyaknya penduduk dan aktivitas di Jakarta menyebabkan banyaknya kendaraan motor dan mobil. Gerald mengatakan bahwa tekejut dengan cara mengemudi kendaraan motor dan mobil, juga dengan banyaknya kendaraan yang ada di Jakarta. Para pekerja Perancis melihat langsung keadaan lalu lintas yang macet dan membuat mereka merasa kaget dengan kondisi pada lalu lintas. Keanehan yang dirasakan dengan lalu lintas di Jakarta yang mengakibatkan para pekerja asal perancis membandingan dengan negaranya.

\section{Reaksi Gegar Budaya yang dialami oleh para pekerja warga Negara Perancis}

Samovar et al (2017:476) menyampaikan bahwa Reaksi Gegar Budaya yang dirasakan setiap individu bervariasi dan dapat muncul dalam waktu yang berbeda. Menurut gegar budaya dapat menghasilkan sejumlah reaksi yang berpotensi mengakibatkan masalah. Paling tidak, gegar budaya dapat menyebabkan anda merasa putus asa, lelah dan tidak nyaman. Bagi para pekerja asal perancis mereka mengalami reaksi gegar budaya. Reaksi tersebut dialami dengan waktu yang berbeda dan gejala yang berbeda. seperti mengalami rasa lelah, ketidaknyaman akibat dari perbedaan budaya dan berada dilingkungan yang sangat berbeda dari Negara asalnya dirasakan oleh pekerja asing asal Negara Perancis. 
Samovar et al (2017:476-477) juga menjelaskan bahwa reaksi yang mungkin dialami ketika menyesuaikan diri pada budaya yang baru yaitu perasaan disorientasi, permusuhan terhadap lingkungan baru, perasaan tertolak,sakit perut dan kepala, rindu kampung halaman, rindu teman dan keluarga, perasaan kehilangan status dan pengaruh, keinginan untuk menyendiri, dan mengaggap anggota budaya yang lain tidak sensitif. Adapun reaksi gegar budaya yang dirasakan oleh pekerja asal Perancis saat tinggal di Indonesia adalah timbulnya rasa rindu akan kampung halaman, merindukan keluarga dan teman-teman. Kerinduan ini kemudian berdampak pula pada kesehatan mereka dan menjadikan mereka merasakan sakit kepala. Selain itu timbul perasaan tidak cocok dengan lingkungan baru. Bagi Para pekerja asal Negara Perancis, Reaksi yang dialaminya mulai dari masalah yang dirasakan saat bekerja dengan pekerja lokal Indonesia membuat pekerja asing Negara Perancis membandingkan negaranya dengan lingkungan baru di Jakarta Indonesia. Hal ini bisa dikatakan bahwa mereka mengalami reaksi permusuhan terhadap lingkungan baru dengan membandingakan Negara asalnya Perancis dengan Negara Indonesia.

Perasaan disorientasi juga dirasakan oleh para pekerja asal Negara Perancis. Karena mereka dikirim dari perusahaannya untuk menyelesaikan proyek yang sedang berjalan di Indonesia. Dalam reaksi gegar budaya dengan mengalami perasaan tertolak yaitu merasa tidak dihargai dan dicampakan oleh pekerja pribumi, tidak dialami oleh warga Negara Perancis. Karena dalam hal ini para pekerja asal Perancis yang datang ke Jakarta adalah orang-orang yang dipercayai perusahaan dengan jabatan sebagai manajer, sehingga tingkat tanggung jawab terhadap perkerjaan tinggi. Serta para pekerja yang dibawahnya akan selalu mendengarkan perintah yang diberinya.

Kekhawatiran terhadap makanan yang ada dilingkungan barunya karena pernah mengalami sakit akibat makanan adalah reaksi yang diungkapkan oleh informan pekerja asal Negara Perancis. Reaksi ini termaksud kedalam reaksi sakit. Karena para pekerja asal Perancis mengalami sakit perut akibat dari makanan dan sakit flu akibat dari keadaan cuaca. Kemudian reaksi rindu dengan kampung halaman atau homesick, kerinduan terhadap keluarga serta teman-teman yang ada dilingkungan asal negaranya diakibatkan dari kebingungan terhadap lingkungan barunya. Adapun khawatir terhadap cuaca yang dirasakan oleh para pekerja asal Perancis berbeda dan aneh karena hujan dan panas serta ketika hujan air yang turun sangat banyak. Dalam hal ini, cuaca yang buruk yang membuat rindu dengan keadaan cuaca lingkungan di Negara asalnya Perancis. Kemudian jarak yang jauh dan tidak dapat bertatap muka secara langsung mengakibatkan kerinduan akan keluarga dan teman-teman.

Perasaan kehilangan status dan perngaruh tidak dialami oleh warga Negara perancis karena mereka memiliki pengalaman bekerja di Negara Negara lainnya sehingga dalam hal tersebut tidak dijadikan masalah oleh pekerja asal Perancis. Tujuan mereka datang hanya untuk bekerja. Selanjutnya reaksi yang dialami dengan menyendiri, hal ini sangat tidak dirasakan oleh para pekerja asal Perancis. Mereka bekerja sehingga dalam hal usia dan kematangan berfikir sudah stabil. Dengan bertemu banyak orang dengan kebudayaan yang berbeda membuat para pekerja asal perancis tidak merasakan kesepian. Serta para pekerja asal Perancis ini sudah memiliki pasangan, sehingga tidak mungkin untuk menyendiri karena lingkungan yang berbeda.

Pada reaksi yang terakhir yaitu Menganggap anggota budaya yang lain tidak sensitif, ini bisa dikatakan bahwa perasaan sensitif dengan hal memiliki perasaan yang besar dengan kepedulian. Para pekerja asal perancis mengatakan bahwa terkadang adanya kesalahan komunikasi karena bahasa yang tidak dimengerti. Serta rasa yang kurang berani bertanya untuk pekerjaan yang di perintahkan. Ketika seseorang mengalami gegar budaya, hal ini dapat menjadi suatu hal baik ataupun buruk tergantung individu memperlakukannya, karena reaksi terhadap gegar budaya pada masing-masing individu berbeda. Hal baik akan terjadi jika pekerja asal Perancis bisa dengan cepat menyesuaikan diri di lingkungan baru dan berbaur namun jika yang terjadi adalah sebaliknya, maka gegar budaya bisa mempengaruhi keadaan fisik maupun psikis. Pada ketiga informan penelitian ini, mereka memiliki perbedaan waktu dalam menyesuaikan diri tetapi tidak lebih dari 3 bulan, hal tersebut beralasan karena mereka sudah diruang lingkup bekerja dan memiliki pengalaman sebelumnya.

Informan pertama Gerald merasakan 3 bulan untuk menyesuaikan diri, lebih lama satu bulan dari informan Louis dan Mehdi yang hanya 2 bulan sudah bisa menerima kebudayaan baru dan merasa nyaman. Hal tersebut karena Gerald lebih banyak berkomunikasi langsung dengan pekerja bangunan yang kurang mengerti bahasa inggris dan dirinya tidak mampu menggunakan bahasa Indonesia dengan lancar. Serta dirinya harus berada dan mengontrol pekerjaan di lapangan atau proyek untuk mengecek keadaan di proyek. Louis merasakan 2 bulan untuk beradaptasi dengan lingkungan baru karena dirinya sudah bekerja di Malaysia sejak tahun 2011 dan Louis menikah dengan wanita asia yang berasal dari philipina, hal tersebut juga memudahkannya dalam beradaptasi pada lingkungan Jakarta yang memiliki kemiripan penduduknya dengan Negara Malaysia dan Philipina. Pada informan Meidi yang merasakan 2 bulan adaptasi dirinya memiliki pengalaman 
yang banyak dengan bekerja sebelumnya di Negara Kamboja. Sehingga membuatnya cepat beradaptasi.

\section{KESIMPULAN}

$\mathrm{B}$ erdasarkan hasil penelitian serta pembahasannya mengenai bentuk- bentuk gegar budaya yang dialami pekerja asal Negara Perancis di kota Jakarta dan Tahapan gegar budaya yang mereka alami, maka diperoleh kesimpulan bahwa pekerja asal Negara Perancis mengalami empat tahap gegar budaya yaitu Fase honeymoon, Fase kekecewaan, Fase awal resolusi dan Fase berfungsi dengan efektif. Dengan memiliki pengalaman yang berbedabeda pada setiap informan, dari kedatangannya ke lingkungan baru dengan rasa senang, bangga dan dirasakan di minggu awal-awal. Selanjutnya mulai merasakan banyak kesulitan beradaptasi dari bahasa, cuaca, kebudayaan, sikap dan sebagainya. Kemudian setelah merasakan beberapa masalah yang mengakibatkan kesulitan dalam berkomunikasi dan menerima lingkungan barunya, tahap ketiga yang dirasakan yaitu menemukan solusi dari masalah yang terjadi dengan menyesuaikan diri, mengenal budaya Indonesia, adanya sikap keterbukaan dan keinginan bersosialisasi. Tahap terakhir yaitu ditandai dengan adanya kenyamanan dengan perbedaan yang ada di lingkungan baru, senang dan para pekerja asing Negara Perancis belajar sedikit menggunakan bahasa Indonesia seperti percakapan sehari-hari.

Pekerja asing asal Negara Perancis juga mengalami reaksi fenomena gegar budaya yaitu seperti lelah, sakit, khawatir, bingung, kecewa, rindu keluarga dan teman dikampung halamannya. Kejadian gegar budaya yang dialami para pekerja asal Negara Perancis yaitu beberapa jenis gegar budaya berdasarkan kategori yaitu bahasa, cuaca, sikap, dan ketertiban. Pada kategori bahasa para pekerja asal Negara perancis mengalami hambatan dalam memahami bahasa Indonesia dan pekerja Indonesia kesulitan memahami bahasa Inggris yang digunakan oleh pekerja asal Perancis sehingga kerap timbul kesalahpahaman dalam pekerjaan. Kemudian pada kategori cuaca dimana Negara Indonesia dan Negara Perancis memiliki perbedaan musim, di ketahui bahwa Negara Perancis memiliki 4 musim. Karena hal ini para pekerja asal Perancis yang bekerja di Jakarta merasakan keanehan pada cuaca. Seperti turun hujan yang mengakibatkan banjir dan cuaca yang panas terik disiang hari namun berakhir hujan lebat. Selanjutnya pada kategori sikap, para pekerja asal Negara Perancis merasakan adanya kekecewaan dengan cara kerja yang dilakukan oleh pekerja bagunan dalam hal kedisiplinan waktu. Terkahir, pada kategori ketertiban dimana terdapat perbedaan peraturan yang dibuat oleh pemerintah di setiap Negara ataupun daerah harus dilaksanakan oleh para penduduknya. Dalam hal ini pekerja asal Negara Perancis merasakan keanehan dengan ketertiban lalu lintas, seperti saat keadaan lalu lintas yang macet, cara pengemudi yang mengendarai kendaraan seenaknya, dan banyaknya pedagang ilegal di pinggir jalan perbatasan lalu lintas memunculkan banyak keheranan bagi mereka.

\section{E. UCAPAN TERIMAKASIH}

$\mathrm{P}$ enelitian ini tentu saja tidak akan dapat terwujud tanpa bantuan dari berbagai pihak-pihak yang telah dengan penuh keikhlasan membantu dari awal penelitian ini dirancang hingga proses penulisan, pencarian data-data, pengolahan, hingga selesai menajadi sebuah tulian penelitian. Untuk itu ucapan terima kasih yang pertama disampaikan kepada jajaran pimpinan, dosen, dan staf di fakultas IImu Komunikasi Universitas Pancasila atas dukungan yang diberikan pada penelitian ini. Selanjutnya ucapan terima kasih juga disampaikan kepada ketiga informan yang telah bersedia meluangkan waktu disela-sela kesibukan mereka sebagai pegawai di PT VINCl untuk diwawancarai. Terakhir, penelitian ini tentu saja tidak akan terwujud tanpa adanya dukunga yang penuh dari keluarga tercinta. Semoga penelitian ini membawa manfaat baik secara akademis dan praktis bagi penulis dan pembacanya.

\section{DAFTAR PUSTAKA}

Ajeng, R. (2016). Komunikasi Antar Budaya Pada Tenaga Kerja Indonesia (Studi Kualitatif Peranan Bahasa Dalam Mengatasi Culture Shock Pada Tenaga Kerja Indonesia Di Korea Selatan Melalui Lembaga Pelatihan Kerja Di Kabupaten Karanganyar). Universitas Sebelas Maret

Basrowi, S. (2008). Memahami Penelitian Kualitatif. Jakarta : Rineka Cipta.

Effendy, O. U. (2007). Ilmu Komunikasi Teori dan Praktek, Cetakan Kesembilanbelas . Bandung : PT Remaja Rosdakarya.

Creswell, J.W. (2010). Research Design Pendekatan Kualitatif, Kuantitatif, dan Mixed.Yogyakarta: Pustaka Pelajar 
Henny, Z. R. I. (2011). Komunikasi Antarbudaya Mahasiswa Korea Selatan di Yogyakarta. Jurnal IImu Komunikasi, Vol.9 No.1.

Itdc.co.id. (2017). ITDC tandatangani MoU dengan Vinci Construction untuk bangun Kompleks Sirkuit Jalan Raya Mandalika. Retrieved Juni 1, 2018, from 2017: https://www.itdc.co.id /corporate/news/itdc-tandatangani-mou-dengan-vinci-construction-untuk-bangun-komplekssirkuit-jalan-raya-mandalika/

Juariyah. (2012). Miskomunikasi Antarbudaya Mahasiswa Pendatang di Kabupaten Jember. Jurnal Ilmu Komunikasi, Vol.10 No.3.

Kemlu.go.id. (2017). Hubungan bilateral Perancis - Indonesia. Retrieved Mei 17, 2018, from 2017: https://www.kemlu.go.id/paris/id/Pages/RI-France.aspx

Kholil, S. M. S. (2017). Komunikasi Antarbudaya Mahasiswa Malaysia Dan Indonesia Fakultas Dakwah Dan Komunikasi. Jurnal Ilmu Komunikasi, Vol.1 No.2.

Liliweri, A. (2002). Makna Budaya dalam Komunikasi Antarbudaya. Yogyakarta: LKIS.

Marnelly, T.Romi. (2017). Dinamika Sosial Budaya Masyarakat Melayu Pesisir (Studi Pengelolaan Madu Sialang di Desa Rawa Mekar Jaya). Jurnal Antropologi: Isu-Isu Sosial Budaya, Vol.19 No.2

Moleong, L. J. (2009). Metode Penelitian Kualitatif. Bandung: PT Remaja Rosdakarya.

Mulyana, D. (2008). IImu Komunikasi: Suatu Pengantar. Bandung: Remaja Rosdakarya.

Mulyana, D. (2014). Ilmu Komunikasi: Suatu Pengantar (Cetakan Ke 18). Bandung: Remaja Rosdakarya.

Mulyana, D et al. (2017). Membongkar Budaya Komunikasi (Cetakan Pertama). Bandung: Remaja Rosdakarya.

Mulyana, R. \&. (2006). Komunikasi Antarbudaya Panduan Berkomunikasi dengan Orang-Orang Berbeda Budaya. Bandung: Remaja Rosdakarya.

Mulyana, R. \&. (2014). Komunikasi Antarbudaya Panduan Berkomunikasi dengan Orang-Orang Berbeda Budaya (Cetakan keempatbelas). Bandung: Remaja Rosdakarya.

Mukhtar. (2013). Metode Penelitian Deskriptif Kualitatif. Jakarta: GP Press Group.

Nationalgeographic.co.id. (2016). Kemesraan Indonesia dan Perancis. Retrieved Maret 14, 2018, from 2016: http://nationalgeographic.co.id/opini/2016/03/kemesraan-indonesia-dan-prancis

Newman, W. L. (2015). Metodologi Penelitian Sosial: Pendekatan Kualitatif dan Kuantitatif. Jakarta: PT. Indeks.

Pikiran-rakyat.com. (2017) Datang ke Indonesia, Prancis Investasi 26 Miliar Dolar AS. Retrieved Mei 20, 2018, from 2017: http://www.pikiran-rakyat.com/ekonomi/2017/03/29/datang-ke-indonesiaprancis-investasi-26-miliar-dolar-397451

Pujileksono, S. (2015). Metodologi Penelitian Kualitatif. Malang: Kelompok Intrans Publishing.

Qureta.com. (2017). Kerjasama Bilateral antara Indonesia dengan Perancis . Retrieved Mei 25, 2018, from 2017: https://www.qureta.com/post/kerjasama-bilateral-antara-indonesia-dengan-prancis

Rahmadhani, F. (2015). Adaptation Of Foreign Teacher In The Process Of Learning In Darma Yudha Highschool Pekanbaru. Jurnal Ilmu Komunikasi,Vol.2 No.2.

Ridwan, A. (2016). Komunikasi Antar Budaya Mengubah Persepsi dan Sikap dalam Meningkatkan Kreativitas Manusia. Bandung: Pustaka Setia.

Ruslan, R. (2016). Manajemen Public Relations \& Media komunikasi: Konsepsi Aplikasi Edisi Revisi . Jakarta: PT Raja Grafindo Persada.

Samovar, L.A et al. (2017). Komunikasi Lintas Budaya (Edisi 7). Jakarta: Salemba Humanika.

Sihabudin, A. (2017). Komunikasi Antarbudaya Satu Perspektif Multidimensi (Cetakan ke 45). Jakarta: Bumi Aksara.

Simatupang, O. L. W (2015). Gaya Berkomunikasi Dan Adaptasi Budaya Mahasiswa Batak Di Yogyakarta. Jurnal IImu Komunikasi, Vol.2 No.5.

Soekanto, S. (2013). Sosiologi Suatu Pengantar (Cetakan ke 45). Jakarta: Raja Grafindo Persada.

Sugiyono. (2013). Metode Penelitian Kuantitatif, Kualitatif dan R\&D. Bandung: Alfabeta.

Tirto.id . (2017). Perancis dan Indonesia dalam Lintas Sejarah . Toyota.co.id. (2017). Special Service Campaign . Retrieved Maret 12, 2018, from 2017: https:/tirto.id/perancis-dan-indonesia-dalamlintasan-sejarah-cj8Z

Tribunnews.com. (2017). Data Imigrasi: Sepanjang 2017. Retrieved Maret 23, 2018, from 2017: http://www.tribunnews.com/nasional/2017/07/05/data-imigrasi-sepanjang-2017-warga-chinapaling-banyak-masuk-ke-indonesia.

Vinci.com.(2018) business line vinci construction. Retrieved Juni 2, 2018, from 2018: https://www.vinci.com/vinci.nsf/en/item/business-line-vinci-construction.htm 